\title{
Pencegahan Tindak Kekerasan Terorisme Demi Perdamaian Yang Berkesinambungan Sebuah Pendekatan Teologi Damai Islami
}

\author{
Martinus Sardi \\ Prodi Hukum, Fakultas Hukum, Universitas Muhammadiyah Yogyakarta \\ Email.msardi@law.umy.ac.id \\ . DOI: $10.18196 /$ ppm.36.309
}

\begin{abstract}
Tindak kekerasan terorisme merupakan fakta social yang ada dalam masyarakat kita, dan tiada hentinya menggoyahkan kedamaian masyarakat. Tindak kekerasan itu seharusnya dapat diatasi dengan pendekatan yang islami. Islam sebagai agama yang damai harus menawarkan jalan yang jitu untuk menjawab tantangan jaman itu. Salah satu cara yag dianggap ampuh tidak lain daripada melaksanakan pencegahannya. Dibutuhkan pencegahan tu untuk dilaksanakan terus menerus tiada hentinya miulai dari tingkat yang paling rendah sampai dengan tingkat yang paling tinggi di masyaraat kita, sehingga perdamaian dan suasana damai akan dapat dinikmati dalam hidup di masyarakat.

Key Words: Pencegahan, Tindak kekerasan, Terorisme, Perdamaian
\end{abstract}

\section{Pendahuluan}

Pencegahan Terorisme Demi Perdamaian yang Berkesinambungan merupakan program teologi Islam yang menantang di masa kini. Berbagai tindak kekerasan yang terjadi akibat terorisme dan konflik horizontal tidak dapat diselesaikan secara profesional, justru karena kurangnya dasar refleksi teologi Islami yang tepat. Islam sebagai agama yang membawa kewajiban untuk mempromosikan damai, haruslah tampil secara profesional dalam menangani masalah tindak kekerasan demi damai yang berkesinambungan. Oleh karena itu dapat digalang adanya masyarakat yang damai dan sejahtera. Tindak kekerasan terorisme dan konflik yang menyebabkan korban tidak boleh terjadi lagi, karena tindak kekerasan itu adalah jahat dalam perspektif islami. Tindak kejahatan ini akan lebih berbahaya dengan adanya tindak kekerasan yang disebut kegiatan teror. Terorisme merupakan tindak kekerasan terhadap umat manusia yang sangat mengerikan dan telah menelan begitu banyak korban manusia.

Terhadap tindak kekerasan terorisme itu haruslah ada tindak pencegahan atau penanganan yang profesional dan manusiawi, dengan tetap memperhatikan martabat manusia.

\section{Metode Pelaksanaan}

Pengabdian masyarakat ini berupa penyuluhan masyarakat mengenai adanya tindak kekerasan terorisme yang sangat berbahaya. Hal ini perlu disikapi dengan cermat dan jeli. Untuk itu masyarakat perlu mengetahui dengan baik berbagai tindak kekerasan itu, dan bagaimana ajaran Islam memberikan pengertian yang tepat mengenai hal itu. Salah satu sikap yang sangat perlu adalah bertindak aktif tanpa kekerasan terhadap realitas sosial terorisme itu. 


\section{Tindak Kekerasan Terorisme Sebagai Realitas Sosial}

Tindak kekerasan terorisme dan konflik merupakan suatu kenyataan sosial yang tidak dapat dipungkiri lagi dan menantang kita untuk menghadapi dan menyelesaikannya. Tindak kekerasan terorisme dan konflik yang berskala besar haruslah kita tanggapi dengan serius dan profesional. Tampaknya tiada hari tanpa konflik dan teror. Teror dan konflik sungguh merupakan suatu realitas sosial yang sangat mengerikan, bagaikan tragedi kemanusiaan yang telah dan selalu mengakibatkan korban manusia.

Di dalam al Qur'an dipertanyakan oleh para Malaikat, ketika Allah akan menjadikan seorang khalifah di muka bumi ini, sbb.:'Ingatlah ketika Tuhanmu berfirman kepada para malaikat: "Sesungguhnya Aku hendak menjadikan seorang khalifah di muka bumi", mereka berkata: "Mengapa Engkau hendak menjadikan (khalifah) di bumi itu orang yang akan membuat kerusakan padanya dan menumpahkan darah, padahal kami senantiasa bertasbih dengan memuji Engkau dan menyucikan Engkau?" Tuhan berfirman: "Sesungguhnya Aku mengetahui apa yang tidak kamu ketahui" (Q.s. Al-Baqarah 2:30).

Pertanyaan para Malaikat itu sangat logis dan menarik, manusia di bumi ini memang membuat kerusakan, saling menghancurkan dan menumpahkan darah, mengapa Allah menjadikannya?. Dengan adanya tindak kekerasan dan konflik yang tiada hentinya ini, korban manusia oleh sesamanya terus berlanjut. Kerusakan, tindak kekerasan dan konflik itu justru disebabkan oleh tangan manusia.

Manusia ciptaan Allah yang seharusnya membangun dunia, malah menghancurkannya. Perbuatan tangan manusia yang jahat, antara lain jelas dalam konflik antar sesama, yang menyebabkan korban manusia dan kehancurannya. Di dalam al Qur'an telah dinyatakan: 'telah nampak kerusakan di darat dan di laut disebabkan karena perbuatan tangan manusia, supaya Allah merasakan kepada mereka sebahagian dari (akibat) perbuatan mereka, agar mereka kembali (ke jalan yang benar) (Ar Rum 30: 41).

Tindak kekerasan terorisme dan konflik yang terjadi di mana pun, di darat, laut, dan di udara selalu menimbulkan kerusakan dan melanggar kemanusiaan. Manusia dijadikan korban oleh ambisi dari adanya tindak kekerasan teror dan konflik itu. Tindak kekerasan dan konflik lahir karena orang tidak mampu untuk mengadakan relasi yang positif, baik dan beradab. Tindak kekerasan lahir justru dari kegagalan orang membangun relasi, komunikasi dan dialog dan adanya tindak kekerasan itu, sesama manusia menjadi korban. Konflik dan tindak kekerasan teror, semua pihak selalu menganggap dirinya yang paling benar, dan pihak lain dinilainya salah dan jahat. Kesadaran untuk berefleksi, melihat dirinya sebagaimana adanya sangatlah sulit dan tak mungkin, kalau tidak ada pihak lain yang ikut campur tangan dan menyadarkannya.

Realitas sosial tindak kekerasan teror dalam skala besar dan professional sungguh mengerikan dan telah merenggut ribuan nyawa manusia. Negara-negara di Asia Tenggara, termasuk Indonesia ini, bagaikan negara yang senantiasa dikuasai oleh teroris. Mungkinkah akan terjadi suatu damai yang berkesinambungan? Kita harus berjuang untuk itu. 


\section{Bertindak Aktif Tanpa Kekerasan Sebagai Sumbangan Islam Dalam Mengelola Tindak kekerasan Teror dan Konflik}

Adanya tindak kekerasan teror yang menyebabkan korban nyawa manusia merupakan tindakan yang jahat, yang sungguh menantang kemausiaan kita. Satu korban manusia saja yang diakibatkan dari adanya konflik itu dapat dinilai "sudah terlalu mahal" dari kaca mata Islam. Nilai manusia atau harkat dan martabatnya itu sungguh agung dan tiada tara harganya. Di dalam al Qur'an dinyatakan bahwa martabat manusia itu tinggi dan sekaligus sebagai ciptaan dalam bentuk yang terbaik (Cfr. QS At Tin 95: 4) dan dianugerahi keunggulan atas makhluk ciptaan yang lainnya (Cfr. QS, Al Isra 17: 70). Disebabkan betapa mulianya nilai dan martabat manusia itu, sampai Allah sendiri memerintahkan para Malaikat sujud kepada Adam. "Sesungguhnya kami Telah menciptakan kamu (Adam), lalu kami bentuk tubuhmu, Kemudian kami katakan kepada para malaikat: "Bersujudlah kamu kepada Adam", Maka merekapun bersujud kecuali iblis. dia tidak termasuk mereka yang bersujud" QS. Al A'raaf 7: 11).

Menyadari betapa agung dan luhurnya martabat manusia itu, sungguh sulit untuk diterima adanya konflik yang mengakibatkan korban sesama manusia. Manusia tidak boleh menjadi korban dari konflik dan tindak kekerasan teror itu. Pada kenyataannya, tindak kekerasan teror dan konflik selalu mendatangkan korban, dan jumlahnya telah begitu banyak. Tindak kekerasan teror dan konflik yang berkepanjangan di berbagai negara di Asia Tenggara ini dapat kita rasakan dampaknya. Seolah agama-agama yang mempunyai pesan damai itu tidak berfungsi sama sekali, atau bahkan orang beragama pun terlibat dalam teror dan konflik yang mengakibatkan korban itu. Bahkan yang sangat sulit untuk diterima ialah agama dipolitikkan, dan terjadi tindak kekerasan teror dan konflik justru lantaran kesalahan penafsiran ajaran agamanya itu. Agama atau bahkan Allah seolah dijadikan dasar dan alasan untuk tindak kekerasan dan konflik, bahkan perang sekalipun.

Kita dapat merasakan adanya getaran dalam sejarah perang salib atau perang sabil, juga perang antara penganut agama Katolik dan Protestan baik di Jerman maupun di Irlandia. Secara sporadis, di berbagai daerah di negara kita yang dipicu justru oleh penafsiran ajaran agama, khususnya antara Islam dan Kristen. Hal ini telah menimbulkan banyak korban. Memang secara resmi tidak pernah dinyatakan adanya perang antarpenganut agama, tetapi kenyataannya pertempuran itu terjadi antaragama yang berbeda. Memang di masa akhir-akhir ini disinyalir juga adanya tindak kekerasan dan konflik horizontal antarumat beragama, tetapi banyak yang diprovokasi dengan bayaran. Suatu tindakan yang tragis dan mengorbankan banyak orang. Kita tidak tahu persis berapa korban tindak kekerasan teror dan konflik di Ambon, Maluku, Kalimantan, dan di berbagai daerah di Jawa ini. Penafsiran agama yang sempit dan penghayatannya yang keliru bagaimana pun juga dapat menjadi pemicu andanya konflik dan tindak kekerasan teror antar umat beragama itu.

Tindak kekerasan teror dan Konflik berdasarkan penghayatan dan penafsiran agama yang sangat picik dapat sangat fatal akibatnya, dan banyak korban berjatuhan, apalagi tindakan itu menjadi tindak kekerasan teror dan betrokan horisontal. Para penganut agama seharusnya selalu memusatkan ajaran agamanya pada Tuhan Allah yang dipandanganya sebagai satu-satunya tujuan hidup matinya. Justru penghayatan akan Tuhan itu dalam tindak kekerasan teror dan konflik menjadi penting. Seolah Tuhan dapat dijadikan Allah pasukan, Allah yang berperang dan manusia penganut 
agamanya menjadi laskar Allah itu. Oleh karena itu berbagai alat perangnya didoakan, diberkati dengan air suci dan dimintakan kepada Allah agar mampu mengalahkan dan jika mungkin malah memusnahkan musuh. Memang terasa aneh hal yang demikian ini, tetapi itulah fakta yang terjadi dan dialaminya oleh manusia penganut agama. Kita dapat melacak dalam sejarah Israel kuno, yang senantiasa minta berkat atas senjatanya sebelum perang, juga dalam tradisi Katolik dalam perang salib, senjata-senjatanya diberkahi oleh Imam, Uskup atau bahkan Paus, agar dapat mengalahkan musuh. Juga banyak Tarekat Religius dibentuk untuk mempertahankan tanah suci, tempat Isa al Masih atau Yesus dahulu hidup. Mereka siap bertempur secara fisik melawan pasukan muslim dalam perang salib dahulu. Fakta sejarah yang mencampuradukkan antara tindakan kekerasan dalam bentuk perang dengan penghayatan iman atau spiritualitas. Mengapa justru tindak kekerasan atau perang direstui oleh para pejabat agama yang resmi, sehingga menjadi perang antarpenganut agama yang berbeda dan begitu banyak korbannya. Entah telah berapa ribu atau bahkan juta manusia harus menjadi korban, lantaran perebutan wilayah yang disebutnya sebagai tanah suci. Perang itu kini lebih dipersempit dengan perang antara Israel dan Palestina, yang sebenarnya merupakan saudara sekandung. Memang bukan perang berdasarkan agama, tetapi kalau dilihat secara mendalam ada unsur semangat agama yang menjadi daya penggeraknya juga, yakni agama Yahudi dan Islam, unsur kekristenan juga ikut memengaruhinya.

Daya penggerak dan semangat berperang berdasarkan agama yakni adanya keyakinan bahwa mati dalam perang yang disebut suci itu akan mendapat ganjaran atau pahala di surga. Korbannya akan disebut martir atau suhada dan diindoktrinasi bahwa Allah akan menerimanya dalam kebahagiaan surgawi. Semangat dan daya penggerak ini ditanamkan pada para pejuang, sehingga mereka pun bertempur matimatian, siap untuk menjadi martir dan akan dianggap sebagai pejuang iman. Ajaran atau slogan demikian ini sebenarnya sangat bertentangan dengan ajaran agama manapun juga, bertentangan dengan spiritualitas dan iman yang sejati. Agama yang seharusnya mengajarkan mengenai damai, malah memprovokasi untuk berperang. Ajaran yang demikian haruslah dipandang sebagai ajaran yang sesat oleh semua agama demi terciptanya damai di bumi ini.

Dalam sejarah Israel kuno, Allah disebutnya sebagai Allah bala tentara, Allah yang berperang dan Allah yang membunuh musuh-musuh Israel. Bangsa Israel bangga karena menganggap dirinya sebagai bangsa yang dipilih oleh Allah dan Allah selalu menjadi Allah bala tentara meraka. Semangat keagamaan yang mendasari perang tetap kuat dan sulit untuk dicabut dari akar-akarnya. Sikap dan tindakan damai yang seharusnya lebih dominan yakni menjadikan bumi ini tempat hidup manusia secara damai belumlah terlaksana. Manusia beragama masih terpukau dengan adanya tindak kekerasan atau bahkan perang, sehingga damai harus diperjuangkan. Damai tidaklah mudah diciptakan, sekalipun telah diperjuangkan dengan gigihnya. Ajaran agama yang menghendaki adanya damai, kerukunan atau rekonsiliasi dapat ditemukan dalam semua agama, tetapi ajaran yang menyatakan bahwa Allah adalah pejuang damai tidak ada dalam Kitab Suci agama apapun. Dengan demikian, kita dapat menyaksikan betapa sulitnya menciptakan damai itu, damai harus diperjuangkan terus-menerus tiada hentinya.

Menghadapi konflik dan betapa sulitnya menciptakan damai itu, orang tidaklah boleh diam saja. Konflik bagaimana pun juga harus diatasi. Dalam menghadapi 
konflik yang nyata, kita dipanggil untuk ikutserta terlibat menyelesaikannya.

Islam sebagai agama yang membawa kewajiban untuk mempromosikan damai, haruslah tampil secara profesional dalam menangani masalah tindak kekerasan dan konflik demi damai yang berkesinambungan. Di dalam al Qur'an dinyatakan: 'Dan hendaklah ada di antara kamu segolongan umat yang menyeru kepada kebajikan, menyuruh kepada yang ma'ruf dan mencegah dari yang munkar; merekalah orangorang yang beruntung" (QS. Ali Imran 3: 104). Di dalam surat yang sama Allah berfirman: "Kamu adalah umat yang terbaik yang dilahirkan untuk manusia, menyuruh kepada yang ma'ruf, dan mencegah dari yang munkar, dan beriman kepada Allah..." (QS. Ali Imran 3: 110).

Sebagai orang yang beriman, kita diperintahkan untuk menjadi pejuang melaksanakan kebaikan dan menolak kejahatan. Konsekuensinya, bila ada kejahatan, dalam bentuk apapun, haruslah ditangani secara profesional. Kelompok yang terlibat dalam konflik sungguh bagaikan telah dibutakan oleh kehendak, keinginan dan ambisinya masing-masing. Penyelesaian tindakan kekerasan teror dan konflik yang benar dan adil merupakan tindakan kemanusiaan yang sungguh dibutuhkan. Penyelesaian atas tindak kekerasan didambakan oleh semua pihak. Penyelesaian itu haruslah memenuhi syarat-syarat yang dibutuhkan untuk dapat hidup sejahtera, dengan bersikap dan bertindak aktif tanpa kekerasan, yang haruslah dapat dipertanggungjawabkan secara objektif.

Secara telogis, kita diwajibkan untuk menyampaikan dengan kata-kata, sikap dan tindakan untuk ikutserta dalam penyelesaian konflik menuju ke perdamaian, dengan melaksanakan kebaikan dan menolak kejahatan. Tindakan ini semakin mendesak, bila kita mempunyai berbagai kemungkinan, kesempatan dan kemampuan untuk itu. Perjuangan untuk tindakan yang demikian itu merupakan kewajiban iman dalam konteks nyata, khususnya dalam tindakan kekerasan teror dan situasi konflik. Iman akan Allah akan semakin kokoh kuat justru karena melaksanakan perintahNya itu. Perwujudan iman menjadi kenyataan hidup justru dalam melaksanakannya secara konkret ini. Berani berjuang untuk mendamaikan mereka yang justru dalam situasi konflik, bermusuhan, bertikai atau bahkan saling berperang. Perang yang nyata dalam situasi sekarang ini adalah perjuangan untuk bagaimana tindak kekerasan teror itu dapat dikikis habis dari muka bumi ini.

\section{Mencegah Tindakan Terorisme Demi Membangun Damai Yang Berkesinambungan}

Tindak kekerasan terorisme yang mengakibatkan korban banyak manusia sungguh sangat mengerikan. Tindakan kekerasan ini tidaklah boleh berkelanjutan, apalagi dengan didasari oleh ajaran agama. Ajaran agama yang memberikan sumbangan terhadap munculnya tindak kekerasan terorisme sangatlah disayangkan dan tidak boleh terjadi lagi. Pada kenyataannya, memang telah banyak sumbangan dari ajaran agama yang memberikan andil munculnya tindak kekerasan terorisme. Hal ini terjadi karena ajaran agama yang benar diselewengkan, dipolitikkan dan ditafsirkan secara keliru.

Penyelewengan terhadap ajaran agama sampai pada indoktrinasi tindakan kekerasan terorisme yang terjadi sekarang ini, bagaimana pun juga harus diatasi. Pencegahan terhadap tindak kekerasan, khususnya berdasarkan ajaran agama sekarang ini saatnya untuk beraksi. Pencegahan itu dapat berupa meluruskan ajaran yang telah diselewengkan dan mengkritisi secara professional berbagai ajaran itu. 
Tindakan kekerasan terorisme bagaimana pun juga tidak pernah ada dasarnya dalam ajaran agama, khususnya al Qur'an. Kitab ini menolak tindak kekerasan terorisme, tetapi harus memperjuangkan perdamaian, yang berkesinambungan. Pada suasana demikian ini haruslah dikembangkan adanya sikap untuk siap sedia untuk saling menyadari, mendengarkan, memahami, mengerti dan menerima satu sama lain, bila perlu dengan koreksi berdasarkan kebenaran dan keadilan.

Keberanian untuk menyelesaikan masalah merupakan keberanian demi kehidupan yang baik, benar dan adil. Hal ini kiranya sesuai dengan Firman Allah: "Sesungguhnya Allah menyuruh kamu menyampaikan amanat kepada yang berhak menerimanya, dan (menyuruh kamu) apabila menetapkan hukum di antara manusia supaya kamu menetapkan dengan adil. Sesungguhnya Allah memberi pengajaran yang sebaik-baiknya kepadamu. Sesungguhnya Allah adalah Maha mendengar lagi Maha Melihat" (An Nisaa 4: 58). Proses penyelesaian masalah merupakan peristiwa historis, yang harus didasarkan pada realitas, fakta dan kebenaran, dan dijalankan dengan adil dan bijaksana. Pendekatan spiritual yang menggunakan bahasa hati sangatlah penting. Keadilan merupakan hal yang sangat penting dan tidaklah boleh diabaikan, sehingga dalam tahap penyelesaian masalah konflik ini tidaklah boleh terjadi korban lagi. Tahap penyelesaian masalah adalah tahap yang serius untuk berbenah diri, merancang masa depan yang cerah dan membuat harapan baru agar damai benar-benar terjadi serta kesejahteraan hidup bermasyarakat dapat dibangun.

Penyelesaian masalah hanyalah suatu peristiwa saja, yang harus ditindaklanjuti dengan menciptakan dan membangun perdamaian. Penyelesaian masalah tindak kekerasan terorisme dan konflik berakhir pada perdamaian satu sama lain atau rekonsiliasi. Rekonsiliasi tidaklah akan berarti banyak kalau tidak diteruskan dengan senantiasa menciptakan dan membangun perdamaian. Hidup dalam suasana damai menantang kita untuk berusaha semaksimal mungkin menciptakan dunia ini semakin damai, bersahabat dan membangun manusia yang paripurna dan sejahtera. Sehubungan dengan hal ini, Allah berfirman: "Dan orang-orang yang berjihad untuk (mencari keridhaan) Kami, benar-benar akan Kami tunjukkan kepada mereka jalanjalan Kami. dan Sesungguhnya Allah benar-benar beserta orang-orang yang berbuat baik" (Al 'Ankabuut 29: 69).

Bila proses ini ditempuh dengan baik, akan terbukalah jalan pengampunan, saling memaafkan, rekonsiliasi, persahabatan, dan sekaligus pengharapan akan jalan yang semakin jelas menuju ke perdamaian yang berkesinambungan itu. Keberanian untuk memaafkan mereka yang telah melaksanakan kejahatan tindak kekerasan terorisme, merupakan satu langkah maju. Suasana damai dan keadilan akan dapat dirasakan dan dihayati. Dalam rangka itu haruslah dibangun suatu budaya damai, dan bukan budaya konflik dan bukan budaya perang. Budaya damai akan mengarahkan manusia untuk mengutamakan damai itu di atas segalanya, agar manusia dapat hidup sejahtera.

\section{Simpulan}

Perjuangan untuk mencegah tindak kekerasan terorisme dan konflik dengan tujuan untuk mencapai perdamaian yang berkesinambungan merupakan tugas yang mulia bagi kita semua. Untuk itu kita berjuang agar damai sejahtera senantiasa terjadi di mana pun juga. Sebagai akhir kata, firman Allah memberikan semangat juang 
kepada kita semua: "Janganlah kamu bersikap lemah, dan janganlah (pula) kamu bersedih hati, padahal kamulah orang-orang yang paling tinggi (derajatnya), jika kamu orang-orang yang beriman" (Ali 'Imran 3: 139).

Berjuang untuk bertindak aktif tanpa kekerasan merupakan ajaran Islam yang sangat penting pada saat ini, dan selayaknyalah dilaksanakan dalam masyarakat. Sehingga perdamaian akan terlaksana dengan baik. Bahkan perdamaian yang berkesinambungan akan terjadi. Tugas bahkan kewajiban umat Islam dalam hal ini perlu dipromosikan.

\section{Ucapan Terimakasih}

Dari hati yang tulus kami sampaikan terimakasih kepada LP3M Universitas Muhammadiyah Yogyakarta, kepada Jamaah Masjid Al Jihad, Masjid Al And, dan para mahasiswa-mahasiswi UMY dan Unisa yang ikut serta dalam pengabdian masyarakat ini. Juga kami haturkan terimakasih kepada Pusat Studi Perdamaian dan Humaniter, UMY dan beberapa Pusat Studi Perdamaian dari Universitas lain yang mendukung usaha kami ini.

\section{Daftar Pustaka}

Barbara Hudson, 2003, Justice in the Risk Society: Challenging and Re-affirming Justice in Late Modernity, Sage Publications, London \& New Delhi..

Christopher Berry Gray (ed), 1999, The Philosophy of Law: An Encyclopedia, Garland Publishing, New York \& London.

E. Shobirin Nadj dan Naning Mardiniah Ed), 2000: Diseminasi Hak Asasi Manusia: Perspektif dan Aksi, CESDA LP3ES, Jakata.

James Bernard Murphy, The Philosophy of Positive Law: Foundations of Jurisprudence (Yale University Press, New Haven and London, 2006).Muladi (ed), 2005: Hak Asasi Manusia: Kakikat, Konsep dan Implikasinya dalam Perspektif Hukum dan Masyarakat, Refika Aditama, Bandung.

Judy Kuriansky, 2007, Beyond Bullets and Bombs: Grassroots Peacebuilding Between Israelis and Palestinians, Praeger, London.

Kurt Tudyka, 1992, The Meaning of Democracy Today”, in: Concilium (5/1992) 4-13.

Lou Goble (ed), The Blackwell Guide to Philosophy of Logic (Oxford, 2008).

Martin P. Golding and William A. Edmundson (ed), 2005, The Blackwell Guide to the Philosophy ofLaw and Legal Theory, Oxford.

Martinus Sardi, 2003: "Conflict, Reconciliation toward Peace in the Indonesian Context: the role of Media and interreligious Dialogue", Proceeding International Seminar: Globalization, Religion, and Media in the Islamic World: Intercultural Dialogue, 
Yogyakarta, Octber 8th - 9 th, 2002 (Atma Jaya Yogyakarta University, Yogyakarta 2003), $207-219$.

Martinus Sardi, 2012: "Manusia Membuat Hukum bagi Dirinya Sendiri: Refleksi Filosofis Atas Hukum Yang Berperspektif Hak Asasi Manusia", in: Menafsir Ulang Strategi Kebudayaan Indonesia (Universitas Atma Jaya Yogyakarta - Penerbit Kanisius, Yogyakarta, 2012), $71-92$.

Martino Sardi, 2012, "Membangun Hidup Beragama yang Beradab Demi Damai Yang Berkesinambungan", dalam Moch Nur Ichwan dan Ahmad Muttaqin (ed), Agama dan Perdamaian: Dari Potensi Menuju Aksi (Program Studi Agama dan Filsafat \& Center for Religion and Peace Studies (CR-Peace), Program Pasca Sarjana, UIN Sunan Kalijaga, Yogyakarta, $3-26$.

Martinus Sardi, 2015: "Membangun Budaya Perdamaian Kawasan Asean Sebuah Tantangan Masa Kini", dalam Ali Muhammad dan Dian Azmawati (ed.), Masyarakat Asram: Problematika, Tantangan dan Strategi, ISBN: 978-602-5450-96-9, Pusat Studi Asean Universitas Muhammadiyah Yogyakarta, dan LP3M, UMY, 2018, hal. 11-22.

Martinus Sardi, 2017, "The Challenges to Build the Culture of Peace in Islam", dalam: Conferences Proceeding: IDACON- International Da'wah Conference; Da'wah in 21 st Century, Bridging Diversity, Enriching Humanity, Yogyakarta, October 4, 2017, Faculty Da'wah and Communication, Sunan Kalijaga State University, Yogyakarta121-132.

Naomi Roht-Arriaza and Javier Mariezcurrena (eds), 2006, Transitional Justice in the TwentyFirst Century: Beyond Truth versus Justice, Cambridge University Press.

Nurul Qamar, 2014: Hak Asasi Manusia dalam Negara Demokrasi (Human Rights in Democratische Rechtsstaat), Sinar Grafika, Jakarta.

Zainal Abidin Ahmad, 2014: Piagam Medina: Konstitusi Tertulis Pertama di Dunia, Pustaka Al-Kautsar, Jakarta. 